\title{
Leisure from International Voices: Foreign Labors' Leisure Opportunities in Taiwan
}

\author{
Chiung-Tzu Lucetta Tsai ${ }^{1}$ \\ ${ }^{1}$ Department of Leisure and Sports Management, College of Business, National Taipei University, Taipei, Taiwan \\ Correspondence: Dr. Chiung-Tzu Lucetta Tsai, Associate Professor, Department of Leisure and Sports Management, \\ College of Business, National Taipei University, Taipei, Taiwan
}

Received: July 29, 2015

doi:10.5430/ijba.v6n5p13
Accepted: August 21, 2015

Online Published: August 28, 2015

URL: http://dx.doi.org/10.5430/ijba.v6n5p13

\begin{abstract}
This research makes an attempt to explore whether or not sufficient public recreational facilities have been provided for foreign women workers in Taiwan and whether or not the general atmosphere makes them afraid to partake in leisure activities. The aim is to apply gender studies in order to understand the different perspectives that foreign female workers have of leisure experience, to explore the social structure and stereotypes which form the power to oppress women and to search for a way to eliminate such oppression and bias. The data for the analysis of these discourses was gathered from documentary analysis and interviews. The collection of informal and formal data enabled the comparison of views that were formally sanctioned by the respondents and those that were informally articulated.
\end{abstract}

Keywords: gender, foreign labors, leisure participation, feminism

\section{Introduction}

As experts in the fields of labor and leisure have focussed only on their respective fields, there is a general absence of researches integrating the subjects of "labor" and "leisure" and the link between "genders" and "foreign workers" has not yet been established. A cross-ethnic study on the leisure activities partaken by foreign women workers will not only help us to understand the views of foreign women workers of different ethnicities on Taiwan's leisure environment, but also what types of leisure activities the foreign women workers in Taiwan are engaging in and what limitations they encounter. In leisure experience, the structure of gender relations is not balanced. Women still face many constraints on leading a fulfilling life outside the home, and the two concepts, sports and leisure, are often seen by women as minor or irrelevant elements in their lives. In this study, I have addressed the creation of gender roles, masculinities and femininities, and their contribution to the development of gender power relations.

In foreign workers' management, Taiwan provided around $20 \%$ of total annual foreign workers management funding (MOL, 2014). The Foreign Workers Employment and Management Group of the Bureau of Employment and Vocational Training of the Council of Labor is responsible for its implementation. Responsible units or departments for management of foreign workers have also been set up within cities' bureaus. Foreign workers' leisure is a key focus for the departments. For example, the important duties of Ministry of Labor include 'conducting recreational activities for foreign workers' (refer to Table 1). In Taiwan, blue-collar workers are defined as those who perform labor-intensive jobs and typically work with their hands. In contrast, a white-collar worker in Taiwan typically performs work in an office environment, which may involve sitting by a computer or at a desk. They are highly skilled and formally trained professionals. Many white-collar workers, such as accountants, bankers, attorneys and real estate agents, provide professional services to clients (MOE, 2013). 
Table 1 The opportunity for leisure activities for white-collar foreign workers

\begin{tabular}{|l|l|l|l|l|}
\hline $\begin{array}{l}\text { Type of leisure } \\
\text { participation of } \\
\text { white-collar foreign } \\
\text { workers }\end{array}$ & $\begin{array}{l}\text { cultural and } \\
\text { recreational } \\
\text { centres }\end{array}$ & $\begin{array}{l}\text { arrangements } \\
\text { for holiday } \\
\text { leisure activities }\end{array}$ & $\begin{array}{l}\text { counselors } \\
\text { provided for } \\
\text { leisure and } \\
\text { work }\end{array}$ & $\begin{array}{l}\text { part of life } \\
\text { counseling } \\
\text { groups }\end{array}$ \\
\hline $\begin{array}{l}\text { foreign workers in } \\
\text { public institutions }\end{array}$ & $26 \%$ & $28 \%$ & $29 \%$ & $8 \%$ \\
\hline
\end{tabular}

Sources: Ministry of Labor (2014)

All people have a basic human right to leisure activities that are in harmony with the norms and social values of their compatriots and therefore, all governments are obliged to recognize and protect this right of its citizens and residents (Athukorala \& Devadason, 2012; Niyogi et al., 2014; Hu et al., 2015). Provisions for leisure for the quality of life are as important as those for health and education. Governments must provide their citizens, including foreign workers a variety of accessible leisure and recreational opportunities of the highest quality (Arora, 2012). The individual is his/her best leisure and recreational resource. Thus, governments should ensure the means for acquiring those skills and understandings necessary to optimize leisure experiences. Individuals can use leisure opportunities for self-fulfillment, developing personal relationships, improving social integration, developing communities and cultural identity as well as promoting international understanding and co-operation and enhancing quality of life (Michaud \& Vermeulen, 2011). Taiwan government has attempted to ensure the future availability of fulfilling leisure experiences by maintaining the quality of this country's physical, social and cultural environment, in addition to this, to ensure the training of professionals to help individuals acquire personal skills, discover and develop their talents, and to broaden their range of recreational opportunities. Foreign workers in Taiwan are expected to have access to all forms of leisure information about the nature of leisure and its opportunities, using it to enhance their knowledge and inform decisions on local and national policy.

The aim of the study is to fill the gap in literature that was identified or the importance of leisure opportunities of foreign female workers, currently there are two objectives to explore whether or not sufficient public recreational facilities have been provided for foreign female workers in Taiwan and whether or not the general atmosphere makes them afraid to partake in leisure activities. The second one is to apply gender studies in order to understand the different perspectives that foreign female workers have of leisure experience, to explore the social structure and stereotypes which form the power to oppress women and to search for a way to eliminate such oppression and bias. Findings in this study have helped to understand the views of foreign female workers of different ethnicities on Taiwan's leisure environment, and what types of leisure activities the foreign women workers in Taiwan are engaging in and what limitations they encounter.

\section{Theoretical Background}

Human resources or labor relations scholars often focus on Taiwan's foreign labor (i.e. Hsin, 2007). Sociologists are concerned with the social situation of foreign workers (i.e. Lan, 2006; Chung, et al., 2008). Other concerns are the economy (for example, Yeh, 2008), human rights (Wang \& Juan, 2007; Soong \& Su, 2008), or policy issues (for example, Hsu, 2006). In the field of leisure, few studies have been concerned with labor or female leisure issues (Tsai, 2011a; Chin et al., 2012; Tsai, 2015). These leisure issues in Taiwan refer to a variety of recreational activities, including opportunities to play sports, visit cinemas, bars and restaurants, go to beauty parlours or spas, go shopping etc. It appears that foreign workers, particularly female ones have a hard time being able to participate in areas such as leisure. Restrictions created by society have also further reduced women foreign workers' willingness to participate in leisure activities. One reason for this lack of previous studies is due to scholars being only concerned with their own fields of research. Research combining 'labor' and 'leisure' therefore is lacking. This is without even mentioning the two other kinds of variables: 'gender' and 'foreign workers.' Cross-ethnic studies of female foreign workers' leisure activities help us understand foreign female workers in Taiwan's leisure space and varieties. The boundary of 'labor' with 'work' in the present society is extremely vague. Work can sometimes be mixed up with leisure in discussions, yet sometimes appear far apart. Wilensky (1960) described the relationship between work and leisure as a spill-over. Work shapes a person's personality while his or her character is presented in leisure time; so strict boundaries cease to really exist between work and leisure (compiled by Rooth, 2011). Leisure can make up for dissatisfaction at work, and work without leisure can form the opposite relationship. In addition, because of workers' limited resources of time and energy, leisure and work consume fixed resources - thus creating a competition. 


\subsection{Work, Leisure and Cross-Nationalism}

The concept of foreign workers' cross-nationalism was proposed by Glick et al. (1992), who believed a new type of immigrant population was rising. They will be in networks of people from their home country and interact with them as well as with those from their country of residence. We call this new concept 'cross-nationalism'. Monika and Santos (2006) in their study of cross-nationalism and leisure of Mexican-American temporary migrant workers found that temporary Mexican-American migrant workers' leisure behaviours can be summarized into four core elements: particular family's status, unique work arrangements, socio-economic and cultural networks, and unique legal status. Particular family's status refers to the responsibility undertaken by migrant workers for family members; unique work arrangements involve type of work, time of work, shift situations, labor-intensive or knowledge-oriented kinds of work. Socio-economic and cultural networks refer to the social situation, economic situation, and racial and cultural context. The unique legal status refers to the situation of foreign workers being protected by the labor or immigration laws in their country of residence. The four core factors that affect the foreign workers are helpful in the construction of the relationship between labor and leisure under cross-nationalism. In comparison to this study, the limit of Monika and Santos' model is that these two are very different groups of immigrants, Mexican-Americans came to the US out of desperation, however, white-collar workers come to Taiwan to experience life. Lan's (2006) study found that 'class' lies at the forefront of Taiwan's foreign labor management policies. The foreign workers understand that only by confronting their current issues will they be able to gain the right and opportunity to pursue leisure.

\subsection{Women's Leisure Opportunities and Provisions}

Gender roles are identified as socially-constructed attributes that are associated with being a man or a woman (Deem, 1986; Tsai, 2009). Masculinities, expressed through masculine discourses, are identified as socially constructed, privileged ways of thinking that dominate society and are often associated with men but may also be associated with women (Whiteside \& Hardin, 2011). In contrast, femininities, expressed through feminine discourses, are socially-constructed ways of thinking, featuring behaviours that are socially understood to be subordinate and are often, but not exclusively, expressed by women (Tsai, 2010b). Moreover, socialcontexts can underlie intercultural conflicts. These are often expressed through cultural differences. Critical Feminism suggests a man's domination over a woman is the most fundamental form of oppression (Tsai, 2006). There is no equality or symmetry between male and female experience (Eckstein \& Lifshitz, 2013). The cultural definitions of female identity made it easier for women to be complacent with the sexual division of labor, reproduction, sexuality and mobility (Ekenga et al., 2015). As female status and mobility became circumscribed and expressed through household production, many wives worked very hard cleaning, washing, and maintaining the family's property (Black et al., 2014). In a sense, females are in general, economically, materially and socially disadvantaged with respect to their take up of leisure opportunities (Aitchison, 2000; Tsai, 2010a). Women's leisure opportunities have traditionally been constrained by their roles as wives, mothers and home makers, whereas men, have been allowed much greater freedom (Wearing, 1998). This traditional inequality of leisure continues to be stronger in Taiwan than in Western countries.

From the above discussion of the literature, it can be gathered that female foreign workers' leisure activities need to be understood from the perspective of cross-nationalism, feminism and labor patterns. The lifestyle and behaviour patterns of foreign workers from different countries come from their home countries as well as from Taiwan (Tsai, 2011b). Gender factors make foreign workers maintain different political, economic and social statuses in the workplace settings and in leisure settings. Different types of work or labor systems at the workplace make female foreign workers partake in different leisure activities (Tsai, 2012). As shown in Figure 1, in the structure of cross-nationalism and feminism, the subjects of consideration in this study include femininity, life courses, fear of space, cultural networks, social classes and economic situations. The statuses of the different types of work arrangements according to labor laws, as well as the employer management style, the type of job, and whether it is in an industrial setting or in the home, affect foreign workers' working hours and rest periods. Moreover, the motivation, content and type of leisure activities also affect female foreign workers' leisure participation. 


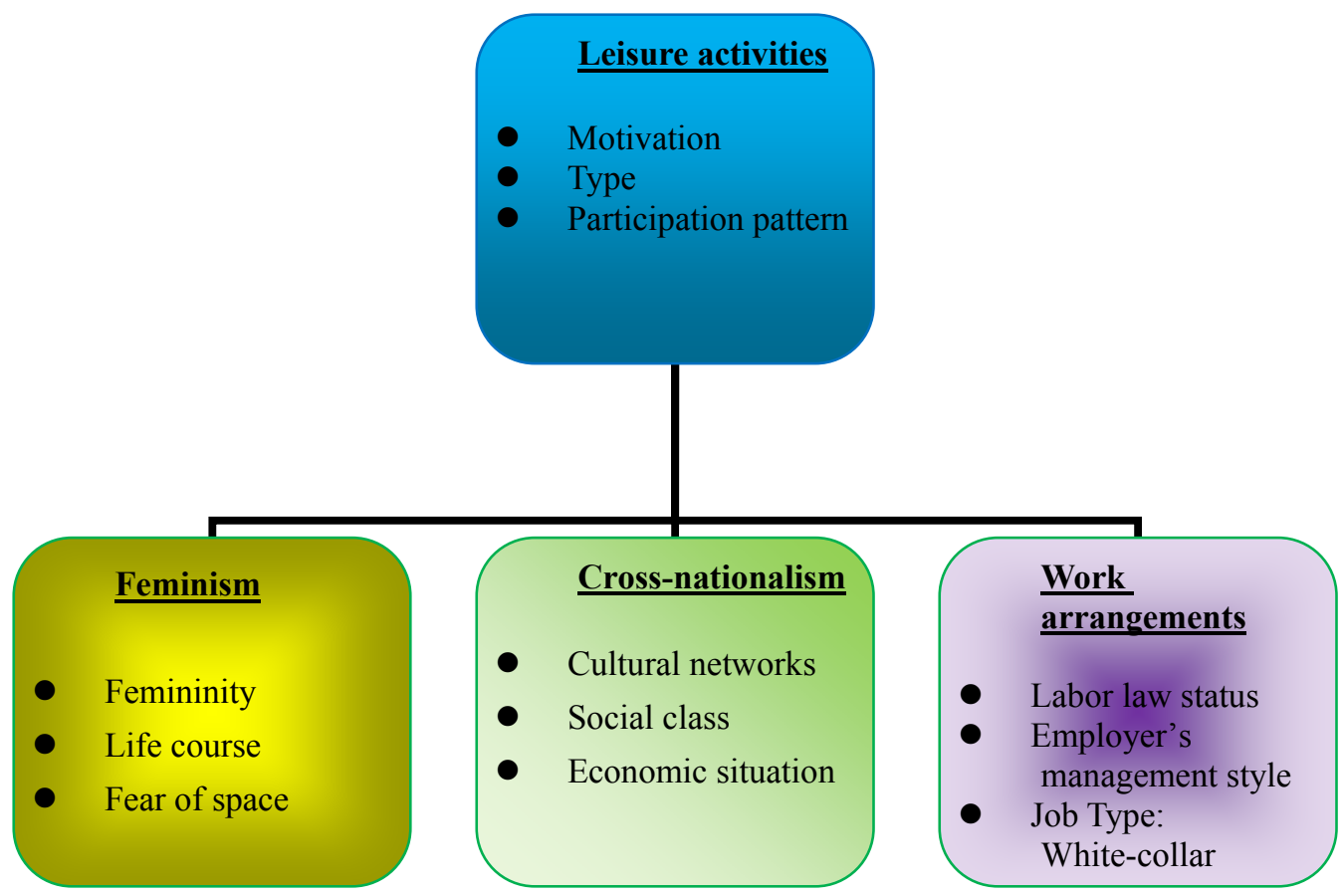

Figure 1. The study subject of female foreign workers in cross-nationalism

\section{Methodological Approach}

In the survey of female foreign workers, according to their labor patterns (refer to Figure 2), the fields of white-collar foreign workers include: industry (such as modern manufacturing industries) and female agency workers (such as workers in English schools) in the country's classification. The white-collar foreign workers encompass the Taiwan government's opening up to major countries, such as the US, Canada, South Africa, Australia, France and the UK

\section{Work arrangements: White-collar \\ Industry female foreign workers Agency female foreign workers \\ US, Canada, South Africa, Australia, France, UK}

Figure 2. Work arrangements and country classification

The study based on the research subject of Figure 1 views the output of its leisure activities research from the perspective of cross-nationalism and feminism, with female foreign workers labor patterns as the intervening variables. From the above discussion, it can be understood that female foreign workers' leisure activities need to be linked with perspectives of feminism and labor patterns. The lifestyle patterns of Taiwan's foreign workers can be affected or altered by their home countries, residential country, gender, political, economic, and social statuses in the workplace and leisure settings. Each of these patterns can uniquely increase or decrease the amount of leisure activities that these workers will participate in. The statuses of the different work arrangements in labor laws, employer's management style, type of job and industrial setting each can affect foreign workers' working hours and rest periods. Moreover, the motivation and variety for leisure activities also affect female foreign workers' leisure participation.

In the survey of female foreign workers, according to their labor patterns, the white-collar foreign workers are employed in all levels of schools and buxiban (cram schools), IT industries or banking. The structure of respondents included female white-collar workers of six different nationalities. Through second-hand data, the observations of cross-nationalism versus global female leisure activities, correlation between labor and leisure activities, collection of data on leisure issues and feminism were employed. Based on empirical data of thirty female foreign workers from the US, the UK, South Africa, France, Canada and Australia, an understanding of cross-country leisure 
behaviour, feminism orientation, and the impact of foreign labor patterns on the female foreign workers was gained. Using critical thinking, cases of similarities and differences were identified as a basis for the field study. Analysis of the influence of feminism on female foreign workers engaged in leisure activities is also observed. The findings of this study could be helpful in the life management of female foreign workers and in the formation of foreign labor management policy.

In-depth interviews with female white-collar foreign workers representing different working modes were conducted. In the interview sampling, special attention was paid to age distribution. Industrial female foreign workers were recommended for interview by the Department of Industry, which employs foreign workers. Each interview took between two to three hours. The interview was divided into two major sections, the first being made up of four general questions and the second of ten specific questions. With the consent of the respondents, the whole process was recorded. Interviews were gradually grouped for the analysis of the studied problems. The research results made type analysis and collation of female white-collar foreign workers' leisure activity and summarized management implications for foreign workers employers and government policy implications. The purpose was to find out if respondents thought opportunities for women were as good as better or worse than in their home countries. The key question was "are you happy with your leisure in Taiwan?"

In addition to interviews, secondary data also provides an important source of information. The importance of documentary evidence is in providing the basis for interview questions such as the informants' views regarding cultural influence and women's freedom. From these documents, interview questions were developed with relevance to the research. For example, regarding the type and contents of leisure activities which interviewees were doing and how much time they spent on leisure. Secondary data were collected from public documents, i.e. newspapers, journal articles, academic books, conference papers, and archival material. Information obtained from local newspapers such as United Daily News and China Times, provides an understanding of topical issues.

Statistical and official documentary sources pertaining to foreign female workers were obtained from the Directorate-General of the Budget, Account and Statistics Department, Executive Yuan; The Council of Physical Education Affairs, Executive Yuan; and the Ministry of Economy. Some government documents were protected and unavailable for either public or private access, requiring the use of a contact (a high-level civil servant) Information was also sought from relevant libraries, such as the Library of the Legislative Yuan; the Library of National Taipei University; and the Legal Room in the National Central Library. Those resources provide specific information on white-collar female workers' leisure in Taiwan, such as their income levels and their job option preferences.

Each interview took between two to three hours, accompanied by a free treat of afternoon tea in a private club. In-depth interviews started with informal conversation, i.e. "Do you like working here", "Do you miss your family?" and "What tourist attractions have you visited in Taiwan?". The interview content had two major items, with ten general questions and fifty-four specific questions. General questions including, "Tell me something about your lifestyle" and "What kind of leisure activity or sporting activities do you pursue?". Specific questions including, "Will you strive for your 'leisure rights' in the future?". It took the researchers six months to conduct the individual interviews in person. After explanation of the process and obtaining consent of the respondents, the whole process was recorded, and after translating the interviews into the transcripts, they were gradually grouped for the analysis of the studied problems. The research results made type analysis and collation of female blue-collar foreign workers' leisure activity, and summarized the management implications for employers of foreign workers and government policy implications of blue-collar foreign workers' leisure.

\section{Findings and Discussions}

In the aspect of leisure provisions, apart from encouraging decision makers in the industry to pay more attention to women's needs, these respondents needed to improve their own leisure experiences and be more active in the participation of leisure activities. It was thought that only men would use public recreational facilities, thus, female demand for leisure facilities was easily overlooked (Azariadis et al., 2013). In traditional thinking in planning leisure facilities, men have the advantage, especially in public areas. Although women account for $50 \%$ of the population, very few leisure facilities are specially set up for them. Some women successfully use existing spaces and facilities, but not all of those in the existing organizations can easily use these facilities, as the obviously dominant groups using these facilities are males (Iwamoto et al., 2009).

All respondents in this study agreed their current careers have affected their leisure opportunities. Regarding their lifestyle in Taiwan, most respondents participated in leisure or sport activities regularly, most went to the gym, at least twice a week. They did not feel the Taiwanese government took care of their leisure needs and wants. More outdoor parks and indoor sports centres were the leisure provisions they expected from government agencies/bodies 
in Taiwan. A Canadian respondent stated,

Of course, I'd like to improve my leisure situation; I expect that the private sector can provide quality leisure provisions and quality places can be increased in Taiwan. I do not think Taiwanese women have got equal leisure rights with men. Before I tried to call Taiwanese female friends to have a cup of tea together, they always wanted to bring their kids. Therefore, our conversation was always interrupted by the little ones and I was forced to be the nanny in the end. As a result, I do not like to go out with Taiwanese moms. I think foreign female workers have got equal sports or leisure rights with foreign male workers in Taiwan.

Some women successfully use existing spaces and facilities, but not all of those in the existing organizations can easily use these facilities, as the obviously dominant groups using these facilities are males (Tsai, 2010a). One French respondent expressed that,

I do not think women should only be involved in the type of exercise which shows their femininity. However, if you have a chance to visit the gym, you will find it is not easy to see women work out in the weights station but in the aerobics or the dance studio. I do weight training in the gym sometimes, I feel the atmosphere is weird, it seems like I am not supposed to come to this place, I'd better go to the dance studio and just tone my body. However, I will not strive for my rights, not even my 'leisure rights' in the future.

In Taiwan, it was thought that only men would use public recreational facilities, thus, female demand for leisure facilities was easily overlooked. Women have higher expectation on clean and safe public spaces, however, this issue is easily ignored by men owing to most decision makers and engineers being men. In traditional thinking in planning leisure facilities, men have the advantage, especially in public areas. In the use of public space, the public has given a more lenient standard to men. Mainstream values of Taiwanese society deem that it is not easy for women to be influential in the group, unless they perform better in the group, provide more positive suggestions, and do not blindly succumb to men in the organization (Tsai, 2014). As one South African respondent stated,

As a foreigner living and working in Taiwan, I would like to gain more leisure opportunities from my employers. I am not willing to spend more money and time in more material leisure pursuits, but would like to have more parks to enjoy. I hope for more open spaces, flexible working hours for Taiwan's foreign workers', furthermore, more funding for foreign worker management counseling and more provision of leisure activities for foreigners.

With patriarchal influence, not to mention the vast majority of resources and development being focussed on men, women's leisure is thus oppressed. Double standards give women greater pressure, leading to their reluctance to leave home to go to public areas for leisure activities (Tsai, 2010b). Whether women have money or not, they are all expected to look after children by themselves. Whilst male partners may be asked to look after children on special occasions, in general there is no real shared responsibility for children and childcare. A modern educated woman therefore has a dilemma - should she sacrifice herself to fulfill family commitments or should she rather pursue her own leisure outside the home? An American respondent stated,

I teach English in the school all day, and when I go home I still have to help the children with their homework, even though my Chinese is poor. My husband scolds me and lose his temper in front of the children, who then get scared and cry. He goes out every night with friends, but I stay at home and have no leisure. But in my hometown in Texas, I would have to help on the farm, so there is no rest there either. I thought that it would be very easy in Taiwan. In fact, there is not much difference.

Although women account for 50\% of the population (United Nations, 2012), very few leisure facilities were specially set up for them. However, this is gradually improving and all the relevant issues have been raised recently. A British respondent described her leisure experiences before and after coming to Taiwan in the following way,

I have more leisure opportunities after coming to Taiwan, because previously in the UK I had very little budget to use for leisure, so I had no means for any leisure. Also I lived in a small village and basically going out at night was a problem. Now that I live in the city and teach English in the kindergarten, I feel I have a decent income, so sometimes I stroll in the department store and shopping centres, enjoying good food and drink. On the weekends, like to watch Taiwan's cultural performances, but the programs are not well introduced in English. I hope the organizers can prepare an English brochure, let me know more about Taiwan.

An Australian respondent who works in a bank stated,

I have more leisure time since I come to work in Taiwan. My work is very busy on weekdays, however, I can enjoy the whole weekend doing wakeboarding with international and Taiwanese friends in Breeze Canal in New Taipei City which is only 15 minutes from the place I live in Australia, the land is massive and therefore, it's not easy for me to 
get to the lake to enjoy wakeboarding. Also the water temperature in Taiwan is just right, on average twenty-five to thirty degree Celsius and therefore, I am quite happy about my water activities with friends at the weekend. Apart from wakeboarding, we also enjoy drinking beers, having a barbecue by the riverside. I hope to work in Taiwan as long as I can.

\section{Conclusions}

This study takes into account the respondents' unique position as both women and temporary migrants. The findings contribute to the development of female foreign workers' leisure while accumulating knowledge for the academic areas of both 'labor' and 'leisure'. For this interdisciplinary study, the three purposes were firstly to explore the impact of cross-nationalism and feminism on female foreign workers' leisure activities. Secondly, this study has examined different labor models' differential impacts and management implications for female white-collar foreign workers in leisure activities. It has attempted to focus on female white-collar workers in order to observe the highest amount of possible subjects. Lastly, it has explored whether or not the recreation supplied in public and private areas is sufficient for female foreign workers' leisure needs.

Although foreign periodicals are not lacking in the analysis of foreign worker leisure issues, this is one of the first attempts in the analysis of leisure activities under cross-nationalism for advanced countries (the US, Canada, South Africa, Australia, France and the UK) by means of cross-country comparisons. For the study of female foreign workers' leisure activities in Taiwan, this study should act as a pioneer; in the past the analytical study of female foreign workers' labor and leisure was almost nil in Taiwan. Therefore to make systematic and specific comparison analysis and discussion for female workers leisure theory and practical operation is helpful in closing this academic gap. The conclusions and findings form further contribution to the knowledge system and theory of Taiwan's leisure, labor, and human resources management. In recent years, Taiwan has been rated by the US State Department as a human trafficking country, making Taiwan's international labor rights an issue of concern. Whether in the Council of Labor Affairs or the labor department of the local county government, the organization of foreign workers' leisure activities has been taken as key policy. However, female foreign workers' and male foreign workers' leisure needs are different. At the same time, the leisure models of foreign workers from different countries differ, and the work arrangements also affect the choice of leisure opportunities for female foreign workers. Therefore, the analysis and results of this study will help the government to carry out more meticulous planning when formulating or organizing foreign workers' leisure activities, to sort out foreign workers' potential problems regarding living counselling or adaptation, and to contribute to the formulation of leisure policies for foreign workers.

\section{References}

Aitchison, C. (2000). Poststructural feminist theories of representing others: A response to the 'crisis' in leisure studies discourse. Leisure Studies, 19, 127-44. http://dx.doi.org/10.1080/02614360050023044

Arora, P. (2012). The leisure divide: can the 'Third World' come out to play? Information Development, 28(2), 93-101. http://dx.doi.org/10.1177/0266666911433607

Athukorala, P. C., \& Devadason, E. S. (2012). The impact of foreign labor on host country wages: The experience of a southern host, Malaysia. World Development, 40(8), 1497-1510.

Azariadis, C., Chen, B. L., Lu, C. H., \& Wang, Y. C. (2013). A two-sector model of endogenous growth with leisure externalities. Journal of Economic Theory, 148(2), 843-857. http://dx.doi.org/10.1016/j.jet.2012.08.005

Black, D. A., Kolesnikova, N., \& Taylor, L. J. (2014). Why do so few women work in New York (and so many in Minneapolis)? Labor supply of married women across US cities. Journal of Urban Economics, 79, 59-71. http://dx.doi.org/10.1016/j.jue.2013.03.003

Chin, M. K., Edginton, C. R., \& Tang, M. S. (2012). School physical education and health: A model of best practice, integrating local context with global trends. The Global Journal of Health and Physical Education Pedagogy, 1(4), 251-282.

Chung, C. C. et al. (2008). A study of leisure participation, job involvement and job satisfaction of amusement parks employees. Journal of Sport and Recreation Research, 2(3), 21-36.

Deem, R. (1986). All Work and No Play? The Sociology of Women and Leisure. Milton Keynes: Open University Press.

Eckstein, Z., \& Lifshitz, O. (2013). Household Interaction and the Labor Supply of Married Women. London: Centre for Economic Policy Research. 
Ekenga, C. C., Parks, C. G., Wilson, L. E., \& Sandler, D. P. (2015). Leisure-time physical activity in relation to occupational physical activity among women. Preventive Medicine, 74, 93-96. http://dx.doi.org/10.1016/j.ypmed.2015.03.003

Glick, N., Basch, L., \& Blanc-Zanton, C. (1992). Towards a Transnational Perspective on Migration: Race, Class, Ethnicity and Nationalism Reconsidered. New York: New York Academy of Science.

Hsin, P. L. (2007). Foreign labor employment and the effect of helping local labors. Employment Security, 6(2), $22-26$.

Hsu, H. Y. (2006). Human right and policy: The case of Kaohsiung MRT Foreign workers' campaign. Taiwan Law Journal, 83, 81-87.

Hu, J., Mao, Y., \& Zhang, J. (2015). The Impact of Non-Labor Income Given Job Heterogeneity on Household Time Allocation: The Evidence from China. Frontiers of Economics in China, 10(1), 113-136.

Iwamoto, J. et al. (2009). Role of sport and exercise in the maintenance of female bone health. Journal of Bone and Mineral Meta-bolism, 27(5), 530-537. http://dx.doi.org/10.1007/s00774-009-0066-6

Lan, P. C. (2006). Legal servitude and free illegality: Control and exit of migrant workers. Taiwan: A Radical Quarterly in Social Studies, 64, 107-150.

Michaud, P. C., \& Vermeulen, F. (2011). A collective labor supply model with complementarities in leisure: Identification and estimation by means of panel data. Labor Economics, 18(2), 159-167. http://dx.doi.org/10.1016/j.labeco.2010.10.005

Ministry of Education. (2013). Chinese Dictionary. Taipei: Ministry of Education, R.O.C.

Ministry of Labor. (2014). Foreign Workers Management and Utilization Survey. Taipei: Ministry of Labor of the Executive Yuan.

Monica, S., \& Santos, C. (2006). Transationalism and Leisure: Mexican Temporary Migrants in the U.S. Journal of Leisure Research, 38(2), 143-167.

Niyogi, R.K., Shizgal, P., \& Dayan, P. (2014). Some work and some play: Microscopic and macroscopic approaches to labor and leisure. PLOS Computational Biology, 10(12). http://dx.doi.org/10.1371/journal.pcbi.1003894.s003

Rooth, D. O. (2011). Work out or out of work-The labor market return to physical fitness and leisure sports activities. Labour Economics, 18(3), 399-409. http://dx.doi.org/10.1016/j.labeco.2010.11.006

Soong, J. J., \& Su, C. P. (2008). Overview of human rights of foreign labor policy in Taiwan. Parliament Journal, $36(2), 7-23$.

Tsai, C. L. (2006). The influence of Confucianism on women's leisure in Taiwan. Leisure Studies, 25(4), 469-476. http://dx.doi.org/10.1080/02614360600898177

Tsai, C. L. (2009). Media systems and their effects on women's sport participation in Taiwan. Sport, Education and Society, 14(1), 37-53. http://dx.doi.org/10.1080/13573320802615023

Tsai, C. L. (2010a). The power game: Cultural influences on gender and leisure. World Leisure Journal, 52(2), 148-156. http://dx.doi.org/10.1080/04419057.2010.9674639

Tsai, C. L. (2010b). A reflection on cultural conflicts in women's leisure. Leisure Sciences, 32(4), 386-390. http://dx.doi.org/10.1080/01490400.2010.488611

Tsai, C. L. (2011a). Dilemma and conflicts in Taiwanese women's leisure participation. Social Indicators Research, 103(1), 131-144. http://dx.doi.org/10.1007/s11205-010-9701-9

Tsai, C. L. (2011b). The participation of leisure activities of female foreign white collar workers in Taiwan. Taiwan Labour Review, 3(2), 147-164.

Tsai, C. L. (2012). Invisible barriers in foreign labours' leisure activities in Taiwan: The case of female blue-collar workers. Taiwan Labour Review, 4(1), 1-28.

Tsai, C. L. (2014). Leisure activities of female foreign workers in Taiwan: transnationalism, feminism and work arrangements. Contemporary Management Research, 10(2), 107-122. http://dx.doi.org/10.7903/cmr.11666

Tsai, C. L., \& Zhou, L. (2015). A cultural confrontation: Western impacts on female college students' leisure opportunities in Taiwan and China. Social Indicators Research, 120(1), 261-276. http://dx.doi.org/10.1007/s11205-014-0574-1 
United Nations. (2012). Statistical Yearbook for Asia and the Pacific wages: The experience of a southern host, Malaysia. World Development, 40(8), 1497-1510. http://dx.doi.org/10.1016/j.worlddev.2012.04.025

Wang, H. R., \& Juan, H. J. (2007). The labor right and life counseling of foreign factory workers. Employment Security, 6(2), 27-32.

Wearing, B. (1998). Leisure and Feminist Theory. Gateshead: Athenaeum Press. http://dx.doi.org/10.4135/9781446278970

Whiteside, E., \& Hardin, M. (2011). Women (not) watching women: Leisure time, television, and implications for televised coverage of women's sports. Communication, Culture \& Critique, 4(2), 122-143. http://dx.doi.org/10.1111/j.1753-9137.2011.01098.x

Wilensky, H. (1960). Work, careers, and social integration. International Social Science Journal, 12, 543-560.

Yeh, T. C. (2008). Relationship between leisure identity and leisure behavior among university faculties-Case study in a northern Taiwan university. Journal of Sport and Recreation Research, 2(3), 150-164. 